\title{
INFLUENCING FACTORS OF INNOVATION IN SURAKARTA CITY GOVERNMENT, CENTRAL JAVA, INDONESIA
}

\author{
FAKTOR-FAKTOR YANG MEMPENGARUHI INOVASI DI PEMERINTAH KOTA \\ SURAKARTA, JAWA TENGAH, INDONESIA
}

\author{
Perdani Budiarti Hayuningtyas ${ }^{*}$, Jun Matsunami ${ }^{2}$, Bakti Setiawan ${ }^{1}$, \\ ${ }^{1}$ Universitas Gadjah Mada, Yogyakarta, Indonesia \\ ${ }^{2}$ Kobe University, Kobe, Japan \\ Corresponding author email: perdanibudiarti@gmail.com \\ Diterima: 10 November 2020, Direvisi: 30 November 2020, Disetujui: 11 Desember 2020
}

\begin{abstract}
After the fall of the New Order regime in 1998, Indonesia changed from a centralized government system to decentralization. By the issuance of Grand Design of Bureaucratic Reform Year 2010-2025 in 2010, public sector innovation cannot be neglected due to the needs for new, innovative, adaptive, and entrepreneurial approaches to bureaucratic reform. Many innovations have been produced in local government to improve their performance. Surakarta City Government is recognized as an innovative city, produce innovative programs, often become examples of good practice in public sector innovation, and appointed as Innovation Laboratory in 2017. This study aims to describe public sector innovation in Surakarta City Government and what factors influencing it. The study was conducted using qualitative research methods with a case study approach and collecting data from interviews and document analysis. The findings of this study reveal that most of the public sector innovation in Surakarta City are ICT based innovation and provides benefits in improving the performance of local governments. Even though there is shifting leadership, the visionary leadership supported by upper-middle managers still plays a crucial role in encouraging innovation in local government, followed by supportive regulations from both central and local government, as well as participation and strong cooperation between sectors. Further, this study draws some recommendations to create an integrated policy to strengthened, evaluate, and maintain the sustainability of public sector innovation in the local government. The local government may provide opportunities to collaborate with NGOs to create public sector innovation.
\end{abstract}

Keyword: innovation, governance, public sector, local government, Surakarta City

\section{ABSTRAK}

Setelah jatuhnya rezim Orde Baru pada tahun 1998, Indonesia berubah dari sistem pemerintahan terpusat menjadi desentralisasi. Dengan dikeluarkannya Grand Design Reformasi Birokrasi Tahun 2010-2025 tahun 2010, inovasi sektor publik tidak dapat diabaikan karena kebutuhan akan pendekatan baru, inovatif, adaptif, dan kewirausahaan terhadap reformasi birokrasi. Berbagai inovasi telah dihasilkan pemerintah daerah untuk meningkatkan kinerjanya. Pemerintah Kota Surakarta diakui sebagai kota yang inovatif, menghasilkan program-program inovatif, sering menjadi contoh praktik yang baik dalam inovasi sektor publik, dan ditetapkan sebagai Laboratorium Inovasi pada tahun 2017. Penelitian ini bertujuan untuk mendeskripsikan inovasi sektor publik pada Pemerintah Kota Surakarta dan faktor-faktor apa saja yang mempengaruhinya. Penelitian dilakukan 
menggunakan metode penelitian kualitatif dengan pendekatan studi kasus dan pengumpulan data melalui wawancara dan analisis dokumen. Temuan penelitian ini mengungkapkan bahwa sebagian besar inovasi sektor publik di Kota Surakarta merupakan inovasi berbasis TIK dan memberikan manfaat dalam meningkatkan kinerja pemerintah daerah. Meski terjadi pergeseran kepemimpinan, kepemimpinan visioner yang didukung oleh pengelola menengah ke atas tetap memegang peranan penting dalam mendorong inovasi di pemerintahan daerah, diikuti oleh regulasi yang mendukung baik dari pemerintah pusat maupun daerah, serta partisipasi dan kerjasama yang kuat antar sektor. Lebih lanjut, studi ini menghasilkan beberapa rekomendasi untuk membuat kebijakan yang terintegrasi untuk memperkuat, mengevaluasi, dan memelihara keberlanjutan inovasi sektor publik di pemerintah daerah. Pemerintah daerah dapat memberikan kesempatan untuk bekerjasama dengan LSM untuk menciptakan inovasi sektor publik.

Kata kunci: inovasi, tata kelola, sekor publik, pemerintah daerah, Kota Surakarta

\section{INTRODUCTION}

Public sector reform has become a big agenda in the world. In the late 1970s and 1980s, New Public Management (NPM) reforms, guided by fiscal stresses, slowly replaced the conventional governance paradigm central to the command and control management style with a risk-averse culture that discouraged creativity in many high-income countries (Arundel et al., 2014). The weakness in the NPM model led to the creation and inefficiency of separate silos within the government. This, in turn, led to experiments in other forms of government, such as "joining government" and networked management, which can foster innovation (Hartley et al., 2013). Such governance types not only provide space for top-down innovation decisions, but also for 'bottom-up' influences, in which middle management and front-line workers may suggest creative ideas and promote their growth.

Regarding innovation, there is a broad concept of innovation so that innovation can be defined in various ways. Previous scholars, such as Rogers (2003), defined innovation as an idea, product, information technology, institution, behavior, values, and new practices or objects which are considered as something new by an individual or society. Meanwhile, Koch and Haukness (2005) say that innovation is a matter of using learning outcomes, namely the use of competencies as a basis for finding new ways of doing things that improve the quality and efficiency of the services provided.

In terms of public sector reforms, innovation cannot be neglected. It is caused by the need for new, more innovative, adaptive, and entrepreneurial approaches to bureaucratic reform. Thus, bureaucratic reform is carried out by finding specific solutions to problems that are deeply explored (Cummings, 2015). On the other hand, the government officials who carried out a repetitive and persistent manner argue that bureaucratic reforms negatively influence the organizational culture that is oriented to innovation. However, the relationship between public sector reforms and innovation can be mutually supportive if the arrangements are properly seated (Wynen et al., 2017).

The Indonesian Government has also realized the importance of public sector reforms. After the fall of the New Order regime in 1998, Indonesia changed 
from a centralized government system to decentralization. It is followed by the issuance of Presidential Regulation Number 81 of 2010 on the Grand Design of Bureaucratic Reform Year 2010-2025 as a starting point to do bureaucratic reform in Indonesia in 2010. This Grand Design is divided into three phases of Road Maps, such as the $1^{\text {st }}$ phase Bureaucratic Reform Road Map (20102014), $2^{\text {nd }}$ phase Bureaucracy Reform Road Map (2015-2019), and $3^{\text {rd }}$ phase Bureaucratic Reform Road Map (20202024).

Moreover, Indonesia has already had strategic documents that refer to innovation as the government's efforts to reform the public sector and instrumental in achieving its broader transparency goals. Notably, the National MediumTerm Development Plan 2015-2019 highlights public innovation as instrumental in improving public services quality and moving towards greater transparency and enhanced accountability. The provisions of the plan regarding public administration and open government reforms emphasize efforts to find new ways of delivering information to the public, to establish e-government systems, and to enhance public engagement in public policy formulation. The current administration's government program (Nawa Cita) commits the government to encourage innovation and development (OECD, 2016).

The importance of developing public sector innovation is also part of a general call for Indonesia to increase its level of innovation. As can be seen in some global reports related to innovation, Indonesia still occupies a low position and lags behind neighboring countries (Prasetyo, 2017). For instance, Indonesia is far behind in terms of innovation, ranked $85^{\text {th }}$ out of 129 countries in the report called Global Innovation Index
(GII) published by Cornell University, INSEAD, and WIPO (2019). It is a very alarming situation since the same report actually states that the most mushrooming innovation activities are in Asia, following the economic slowdown in developed countries and the world. Based on this report, strong government planning in policies that drive innovation is the key to success. However, Indonesia is still lagging behind in terms of $R \& D$ and investment activities.

In order to improve innovation in the public sector, the need to mainstream innovation in governance can be seen in the increasing number of awards given for public sector innovation in Indonesia. For instance, Public Service Innovation Competition (Sinovik) organized by the Ministry of Administrative Reform and Bureaucratic Reform has been running since 2014, Innovative Government Awards (IGA) by the Ministry of Home Affairs, and the Solution Innovation Contest and Open Government Competition both of which are provided by the Presidential Work Unit for Development Supervision and Control.

In terms of improving local government performance, it can be done through public sector innovation to bring services closer to the community. In Indonesia, by the enactment of President of Republic Indonesia Regulation Number 38 the Year 2017 regarding Regional Innovation, it gives authority to local governments to develop policies. In this case, Sururi (2017) stated that the role of local public officials in innovating public policies will increase and have a positive impact on the quality of policies or regulations that will be developed and produced.

Moreover, public sector innovations are on the rise in Indonesia. According to Yunita (2017), there are two causes for the rise of innovation, namely 
the existence of a regional innovation laboratory and leadership training. Thus, since 2015, the National Institute of Public Administration through the Innovation Laboratory uses their original method called 5D (Drum-up, Diagnose, Design, Deliver, and Display) to assist local governments in improving their performance through innovation creation (Prasetyo, 2017).

In the case of Surakarta City, even though categorized as a big city, this city is only $44 \mathrm{Km}^{2}$ width. This causes Surakarta City to face challenges that are also faced by other regions in the population sector. Apart from population density that happened because of the increasing population, the development in Surakarta City is slightly hampered due to infrastructure inequality, lack of natural resources, transportation congestion, poverty, as well as limited City budget sources. Thus, Surakarta City needs to do innovation in solving various complex public service problems.

Surakarta City Government has already implemented innovation in some of its policies for more than a decade. Post Reformation era (New Order) in 1998 and the leadership of former mayor Joko Widodo from 2005-2012, Surakarta City Government experienced a new era of governance and was recognized as an innovative city by receiving some awards in public sector innovation due to some innovative policies and programs applied in the city. For instance, UNICEF Award for Child Protection Program (2006), City with the 2nd Best Spatial Planning in Indonesia Citra Bhakti Abdi Negara Trophy and Charter from the President of the Republic of Indonesia for the city's performance in providing public service facilities, deregulation policy, discipline enforcement, and service management development (2009), Citra Trophy for National Level Excellent Service by the
State Minister for Administrative Reform of the Republic of Indonesia (2009), Award from the Ministry of Finance in the form of a grant of 19.2 billion for the implementation of good financial management (2009), the field of Excellent Service Innovation Pioneer (2010), and the best cities for implementing the development program to create a ChildFriendly City (2011) (Zulsyid, 2014).

Surakarta City was also categorized as a very innovative city by the Ministry of Home Affairs. ${ }^{1}$ The innovative programs carried out by the Surakarta City Government are often used as models for Central Government and other Local Government. For example, Surakarta City had already created an Incentive Child Card to provide some facilities and support children's welfare since 2009 and the Central Government adopted this program and made it into a national program called Child Identity Card, by issuing Minister of Domestic Affairs Regulation Number 2 of 2016 on Child Identity Cards. This condition makes other regions come to Surakarta City to learn about their innovative programs and later adopted it to their policy in their region.

Furthermore, in 2017, this city became an Innovation Laboratory to strengthen the local government's capacity to innovate. By the end of 2017, Surakarta City Government held an event called Exhibition of Innovation Works as the last step of the 5D model of innovation created by the National Institute of Public Administration. This event highlighted 70 innovations developed in 44 offices in Surakarta City Government. Among three winners of Innovation Lab in 2017, two innovations have been chosen as the winners of innovation competition in the

1 Based on Ministry of Home Affairs Decree Number 002.6-415 of 2019 
Provincial and Central Government. However, one innovation is rarely known by the public and some function of this innovation has to be merge with other previous innovation. On the other hand, there are some innovations created before Innovation Lab which are still running until now, such as Surakarta Complaint Service Unit, proving the sustainability of this innovation.

There have been previous studies regarding public sector innovation. Borins' (2001a) study which uses research based on applications to the Ford-KSG awards and two other innovation awards in the US, investigate about how public sector organizations could be made more innovative. He categorizes the reasons motivating innovation in the public sector into five main groups. First, initiatives coming from the political system due to an election mandate to the legislation or political pressures; second, new leadership or new managers of a public organization; third, a crisis, which is defined as a current or anticipated publicly visible failure or problem; fourth, a variety of internal problems, such as the inability to reach a target population, inability to meet the demand for a program, resource constraints, or an inability to coordinate policies; and fifth, the new opportunities that resulting from technology or related to other causes. Based on his study, Borins explained that the most influencing factor is internal problems, followed by crises, political influence, new opportunities, and the last one is new leadership. Moreover, Borins explained that there is a great deal of innovation coming from the front lines and in middle management. Most of it is not crisis-driven, but instead a proactive reaction to internal challenges or opportunities. Thus, these innovative ideas have to be supported by top managers, and crisis is not a necessary condition for public sector innovation.
Meanwhile, Gabris et al (2009) stated that the public sector can arise and be successful with three factors. The first factor is leadership credibility since organizations need managers who are innovative leaders; managers who are believable, acting in a logical, coherent way, and able to implement by themselves. The second factor is team management, in which innovation requires the teamwork of individuals who have frequent communication, who have complementary skills and knowledge, and who trust and respect each other. The team member who creates innovation will have a sense of ownership of the innovation and a responsibility in ensuring that the innovation will be successful. The last factor is the governing board functioning or the collaboration of the town council representatives or politicians.

In their study in 2011, Osborne \& Brown summarized five lessons to encourage and support public service innovation in the UK. First, understanding the complexity of innovation to allow more clear and effective policymaking, as well as the more successful management of the innovation process. Second, the individual agency by itself is a necessary but not a sufficient condition for innovation in public service organization and political mandate for innovation is also essential. The third lesson, it is not possible to promote and sustain innovation simply by focusing on the organization alone since an open systems orientation is important. The fourth lesson is to embrace a service-oriented approach that emphasizes the distinctive characteristics of services, the primacy of process in services delivery, and the role of the service user as the co-producer of innovation. The final lesson is that political context must at the very least be understood as the environment for innovation in public services and should 
not obscure the need for organizational and service-learning from innovation, especially failed innovation. Moreover, this study also suggested further studies about innovation in the public sector need to explore organizational, environmental, and institutional conditions to ensure the continuity of public sector innovation.

In 2016, De Vries et al. investigate 181 articles and books on public sector innovation, published between 1990 and 2014 through a systematic literature review. They develop an empirically based framework of potentially important antecedents and effects of public sector innovation. Some antecedents can be drivers or barriers in the public sector innovation. First, the environmental level, such as media attention, political demands, public demands, regulatory aspects, participation in the network and interorganizational relationship. Second, an organizational level that is related to organizational structure, information, time, money, ICT facilities, leadership style, incentives/rewards, and clear goals. Third, innovation characteristics in which the complexity of the innovation ease in the use of innovation, relative advantage, compatibility, and trialability. The last factor is the individual/employee level or ability, such as empowerment, skills, creativity, and commitment. De Vries, et al. (2016) also suggested future studies need to focus more on theory development and testing as previous studies were theoretically weak. Furthermore, more cross-sectional as well as cross-sectoral studies connecting various governance and state traditions and the effects of public sector innovation.

A previous study about Innovation Design in Local Government is conducted by Noor in Jembrana Regency in 2017 . He used quantitative approach using secondary data methods and proposed a model that he called the LPC model
(Leadership, Political, and Climate) to design innovation in local government. The first one is leadership that is consists of leadership style and leadership vision. The second factor is a conducive political environment, which related to a political party and political provenience. The last factor is a supportive organizational climate, which consists of structure and rewards. Those three factors in LPC Model can act as leverage innovation as well as a barrier to innovation. Noor said that innovation is not linear and influenced by many factors. It is required comprehensive knowledge in terms of local government value to develop an innovation culture in the public sectors organization such as local government. Furthermore, Noor suggested testing his proposed model in another local government in Indonesia with different condition.

Based on the existence of Surakarta City as innovative city and previous studies, it can be found that study of innovation in the public sector has emerged in recent decades. However, most of them are carried out mostly in developed countries, such as the U.S. and Canada (Borins, 2001a; Borins, 2001b), and the U.K (Osborne \& Brown, 2011). However, studies about innovation in the public sector in developing countries focus on local government using in-depth interview is under-researched. Thus, it is important to conduct studies to investigate the innovation development in Surakarta City Government and what factors influencing it. This study will potentially provide input to make improvements and recommendations to policy-related innovation in the local government. Moreover, the result of this study may become a reference for other city governments in order to create and improve its innovative programs. 


\section{METHOD}

This research uses a qualitative approach with a case study method. Through exploratory activities, the results are presented in the form of descriptive narrative. According to Yin (2014), the case study method allows researchers to retain the holistic and meaningful characteristics of real-life events such as individual life cycles, organizational, and managerial processes. Accordingly, the qualitative research method was chosen to address the proposed questions. Thus, this study is conducted by qualitative method which focus on the actors who involves in the birth of public sector innovation in Surakarta City as spatial scope.

There were two kind of data in this study, primary and secondary data. The primary data is collected through in-depth interviews using a semi-structured questionnaire as an interview guide for the researcher in this study. The in-depth interviews are conducted with purposive sampling to reveal opinions about the current innovation condition in Surakarta City Government. The informants consist of the government officials who involved in innovation process, such as government officials from Regional Research and Development Planning Board, Regional Employment Board, Regional Financial and Asset Management Revenue Board, Organization Division of Regional Secretariat, Development Administration Division of Regional Secretariat, Public Works and Urban Planning Office, Population and Civil Registration Office, and Inspectorate. Moreover, NGOs, academicians, and political party, are also being interviewed to provide their opinion about innovation in the local government. The secondary data is collected by conducted literature study from documents, government report, books, journals, newspapers, websites, and other reliable sources of evidence.
In this study, there are three independent variables and a dependent variable to examine the innovation in the local government. Based on these variables, some questions are developed to explore perspectives of the stakeholders on innovation the public sector. The independent variables consist of visionary leadership, organizational climate, and enabling environment, while the dependent variable is innovation in the local government. The first factor is a visionary leadership. A leader who has a vision, understands the potential of the region, believable, welcome new idea, and supported by a supportive upper-middle manager will encourage innovation in the public sector. A participative leadership who involves the use of various decisionmaking procedures that determine the extent to which people can influence leaders' decisions and have autonomy to design and guide their tasks. A visionary leadership is perceived as an essential factor who understands the potential of the region, believable, welcome new idea, and involves the use of various decisionmaking procedures (Gabris et al., 2009; Noor, 2017).

The second independent variable is organizational climate. Organizational climate is identified by several indicators, such as organizational structure, time, money, ICT facilities, incentives/rewards, and clear goals. In the public sector, individuals who have frequent communication, who have complementary skills and knowledge, and who trust and respect each other, will build a good teamwork (Gabris et al., 2009). A positive organizational climate will enhance innovation in the public sector (Noor, 2017).

The last independent variable is enabling environment. It is related with political demands, public demands, regulatory aspects, as well as participation 
in network and inter-organizational relationship. The governing board functioning or the collaboration of the town council representatives or politicians to create regulatory that support innovation (Gabris et al., 2009). A positive political situation (Noor, 2017), a good participation in the network, and interorganizational relationship will support innovation in the public sector (De Vries et al., 2016; Noor, 2017). Thus, a combination of those three variables will affect innovation in the public sector and its sustainability. Innovation in the local government is identified as some innovations created in Surakarta City Government.

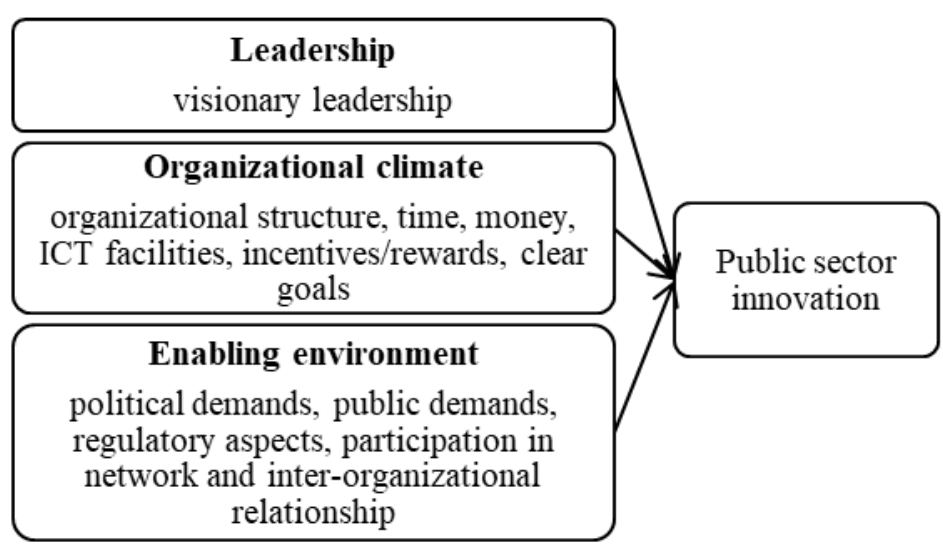

Figure 1

Theoretical framework modified from Noor (2017) supported by Borins (2001a), Gabris et al. (2009), and De Vries et al. (2016)

According to Miles et al. (2014), analysis in qualitative is divided into three stages that occur together, such as data condensation, data display, and drawing and verifying conclusions. Data obtained through observations, interviews, analysis of documents, field notes, and literature review is compiled and elaborated in the form of narrative descriptions to get findings to be discussed and draw conclusions from these data.

\section{FINDINGS AND DISCUSSION \\ Findings \\ Development of Innovation in Surakarta City Government}

After the Reformation era (New Order) in 1998 and the leadership of former mayor Joko Widodo from 2005-
2012, Surakarta City Government experienced a new era of governance. Different from their predecessor who implemented the technocratic approach using experts' ability to apply for programs but lack of communication and dissemination of government policies with the stakeholders (Holidin, \& Handini, 2014), Joko Widodo and F.X. Hadi Rudyatmo chose to do open communication and collaborate with the stakeholders. Their efforts to revitalize the Banjarsari Park as an open green space by relocating secondhand goods street traders experienced nearly no turmoil. They held more than 50 meetings with representatives of the street vendors and NGOs to collect their demands, asked the city officials and academics to conduct research about the street vendors real 
conditions in the field, and met legislative councils to discuss the relocation's budget so that the best solution for both city government and street vendors would be generated. This program is considered as one successful innovation from Joko Widodo and F.X. Hadi Rudyatmo in making good communication with people (Majeed, 2012).

The programs carried out by the Surakarta City Government are often used as models for implementing innovations that are generally not carried out by the regional government in general (Handini, 2016). For example, Surakarta City had already created Incentive Child Card to provide some facilities and support children's welfare since 2009. As stated by the Head of Data Utilization and Service Innovation Division of Population and Civil Registration Office, this innovative policy then adopted by the Central Government and made it into a national program called Child Identity Card, by issuing Minister of Domestic Affairs Regulation Number 2 of 2016 on Child Identity Cards.

Other than that, Surakarta City also received some awards in public sector innovation for some of its innovative programs applied in the city. For instance, Surakarta City was awarded as the Number One Pro-Investment City in Central Java in 2009 and for Pioneer Service Innovation from the Ministry of Administrative and Bureaucratic Reform and Innovative Government Award 2010 from Ministry of Home Affairs. In 2017, Surakarta City was chosen as one of the 100 Smart Cities Pilot Project of the Ministry of Communications and Information Technology. In the same year, Surakarta City became an Innovation Laboratory of the National Institute of Public Administration of the Republic of Indonesia. Furthermore, Surakarta City received Innovative Government Awards from 2017 to 2019. In 2019, Surakarta successfully propose 41 innovations consist 4 governance innovations, 21 public service innovations, and 16 other innovations originating from 27 offices in Surakarta City Government to Innovative Government Awards Competition. In the same year, Surakarta City also became the General Champion of the Regional Competitiveness Index Award of the Central Java Province.

After Joko Widodo elected as Governor of Special Capital Region of Jakarta in 2012, F.X. Hadi Rudyatmo replaced him as the mayor, and his leadership has not differed much from his predecessor. He continued some programs that have been planned in the Regional Mid-Term Development Plan 2010-2015. By the end of 2015, together with Achmad Purnomo as the vice mayor candidate, F.X. Hadi Rudyatmo run as Mayor for 2016-2021 in the Regional Election and won against Anung Indro Susanto and Muhammad Fajri by gaining around $60 \%$ vote (Wibowo, 2015).

The vision and mission of the elected Mayor and Vice Mayor, as explained in Surakarta Mayor Regulation Number 9 of 2016 on Regional Mid-Term Development Plan of Surakarta City Government 2016-2021, is the realization of Surakarta as a cultural, independent, advanced, and prosperous city. Innovation is one of the strategic issues in this midterm development plan document, and the implementation of innovation is one of the target indicators that need to be achieved by Surakarta City Government. Therefore, Surakarta City Government has tried to encourage innovation in every work program of the Mayor, including enhancing the government officers' capacity.

The existence of a regional innovation laboratory and leadership training there are two causes for the rise of 
innovation in the public sector (Yunita, 2017). In Surakarta City Government, the initiation of the Innovation Laboratory started in 2017, when the National Institute of Public Administration offered Surakarta City Government assistance to develop the Innovation Lab. As stated by Head of Sub-Division of Selection and Certification of Education and Training Division of Regional Employment Board: "the Mayor delegated the assistance to the Regional Employment Board due to his opinion that Innovation Laboratory is related with government officer's capacity building. The Head of the Regional Employment Board then instructed the Training and Education Division to handle this task since this division facilitated the government officers who will participate in the leadership training to create Project of Change." Thus, the collaboration of Innovation Lab and Leadership Training is expected to encourage the birth of innovation in local government. Without too complicated procedures, the idea to implement Innovation Lab can be executed in the same year.

By the end of 2017, Surakarta City Government held an event called Exhibition of Innovation Works as the last step of the 5D model of innovation created by the National Institute of Public Administration. This event highlighted 70 innovations developed in 44 offices in Surakarta City Government. The top three innovations are selected in order as: 1) Death Certificate Administration Service that belongs to the Population and Civil Registration Office; 2) Online Tax Payment System that belongs to the Regional Revenue, Financial Management, and Asset Board; and 3) Public Works Integrated Information System created by Public Works and Spatial Planning Office. The top innovation won 15 million IDR, the second-best 10 million IDR, and the third- best 7.5 million IDR, which is allocated to further developing their innovation in the future.

Among three winners of Innovation Lab in 2017, two innovations called Death Certificate Administration Service and Online Tax Payment System have been chosen as the winners of innovation competition in the Provincial and Central Government. However, since there are some innovations created before Innovation Lab which are still running until now, such as Surakarta Complaint Service Unit which is created in 2013. Thus, it is important to compare three innovations produced through the 2017 Innovation Laboratory and one innovation that resulted from collaboration with NGOs since 2013 to examine the development and the longevity of these innovations.

\section{1) Innovation in Death Certificate Administration Service}

This innovation was developed since the level of awareness of citizens to register the death certificate documents in Surakarta City is still low. This situation happened because of limited time to obtain death certificates and most people only register it when they are in need in managing inheritance rights. The problemsolving initiative of making death certificates was supported by the Mayor since this innovation uses proactive service so that government officers can deliver the administration population service directly to the community. He even asked the Population and Civil Registry Office to prepare the ICT infrastructure to support the implementation of the Death Certificate Administration Service program.

Moreover, the Mayor was also supportive of this innovation since the death certificate administration service collaborates technology with local manners. It is stated by the Head of Data 
Utilization and Service Innovation Division of Population and Civil Registration Office: "The Head of Urban Village, who gives a speech at funerals to express condolences to grieving citizens, can directly provide families with Death Certificates, an updated Family Card, and an electronic Identity Card. This innovation shortens the steps required to make a death certificate as surviving family members no longer have to go directly to the Population and Civil Registry Office to apply for the death."

The Population and Civil Registration Office has the most innovative programs since they have the Innovation Division in order to increase their performance in giving public services. The innovation division of Population and Civil Registration Office focus on its job to create innovative programs to solve the problems face in the office's daily jobs. There is a routine meeting hold by the Head of Population and Civil Registration Office to discuss the problem so that they will find an innovative solution for their internal problem.

Death Certificate Administration Service is an innovative program that simplifies procedures by using the population administration registrar in every Urban Village to serve the community and decreases the processing time for documents by utilizing ICT. All population and civil registration data are integrated in the Information System of the Population Administration, and the ICT infrastructure is provided by Communication, Information, Statistics, and Encoding Office. The main obstacle faced when using ICT facilities is network problems. The connection is sometimes unstable, not allowing for uploading or downloading files. To overcome this problem, an alternative way to upload the required files is through WhatsApp so that the requested file can still be processed at Population and Civil Registration Office.

This innovation has increased the number of death certificates issued in Surakarta City. In 2015, the Surakarta City Population and Civil Registry Office issued 2,961 death certificates, and in 2016, 3,513 death certificates were issued. In $2017,4,220$ death certificates were issued, an increase of $20.13 \%$ compared to the previous year. The recent data show that from January 2018 through July 10, 2018, 3,774 death certificates were issued. If it is compared with the issuance of the death certificate in 2017, the achievement for approximately 6.5 months was $89.43 \%$. Meanwhile, the achievement in the first 6.5 months of 2018 was $107.42 \%$ of the total issuance of deeds in 2016 (3,513 death certificates). It is in line with the goals of this program: to shorten the procedure of providing death certificate making service and to increase the number of death certificates issued to provide an accurate population registration database.

The success of this innovation leads the Ministry of Communication and Information to believe that the Death Certificate Administration Service can be duplicated in other regions. The Ministry considers the program is effective in providing information technology public services (Ariawan, 2020).

The Regional House of Representatives as the legislative body supports the idea of the Death Certificate Administration Service by providing budget during the budget planning process. As informed by the Head of the Prosperous Justice Party who also a member of Commission III: Economy and Financial Issue of Regional House of Representatives, "political parties tend to support the innovative program since it provides benefits to community. Innovation in basic population services in Surakarta City, such as Death Certificate 
Administration Service, is already quite effective, so there is a need to manage the sustainability of that innovation."

Death Certificate Administration Service innovation supports the existence of Surakarta City Regional Regulation Number 1 of 2015 on Implementation of the Population Administration. After implemented in 5 pilot Urban Village in 2017, in early 2018, all Urban Village in Surakarta City implemented this innovative administration service by the enactment of Surakarta Mayor Regulation Number 1 of 2018 on the Condolence Death Certificate Program. This regulation regulates the targets and types of documents issued, requirements, procedures for reporting and issuance of documents, and document submission. This innovation is a sustainable policy that is strengthen Surakarta City commitment. This innovation can be considered as continuity of population policy in Surakarta City to integrate population data with development planning so that development programs are better targeted. Due to this commitment, Surakarta City is also chosen Best City in the 2016 Population Development Category (Rakhmatullah, 2016).

\section{2) Innovation in Tax Payment System}

The Online Tax Payment System is a more accurate, fast, and accountable tax payment system that accelerates and simplifies the monitoring system by top managers and middle managers of local tax services. The innovative tax payment system is developed constantly due to an unintegrated potential tax database due to manual system applied in the office. The taxpayers still pay taxes conventionally in the Regional Financial Revenue and Asset Management Board, and the reported income from taxpayers is not real-time.

The Regional Financial Revenue and Asset Management Board does not have an innovation division like
Population and Civil Registration Office does. However, the head of the Regional Financial Revenue and Asset Management Board, is an innovative person who strongly engaged with ICT development. As stated by former Head of Tax Division of Regional Financial Revenue and Asset Management Board 2016-2019: “He encourages staff members to generate ideas related to innovation in ICT to increase office performance. Online Tax Payment System was a direct result of this encouragement."

This online tax payment system is also supported by the Mayor since the goals of this innovation is to increase Local Government Revenue. Moreover, this innovation prevents criminal acts of corruption, supports the disclosure of public information, and transparency in tax collection. Another goal is budget efficiency, human resources, to transparency and accountability in governance.

Since Online Tax Payment System is an innovative program that simplifies procedures of the tax payment system, ICT became the main tool in this public service. All staff members involved in the implementation of this tax payment system are trained in this new system. Online Tax Payment System is also integrated with Solo Destination, a mobile phone application based on Android and IOS platforms. However, this ICT related innovation need a good infrastructure and need a good

Not only improves the transparency and accuracy of services as well as optimizes the achievement of Local Government Revenue targets of the local tax sector, but this innovation also encourages the increasing of Local Government Revenue. It can be seen from the figure below that there is an increase in Local Tax Revenue from 252 billion IDR (17 million USD) to 360 billion IDR (250 
million USD) in 2019 since the launching of the Online Tax Payment System in 2017. It is predicted by Regional Financial
Revenue and Asset Management Board that the local tax revenue will reach 370 billion IDR (260 million USD) in 2020.

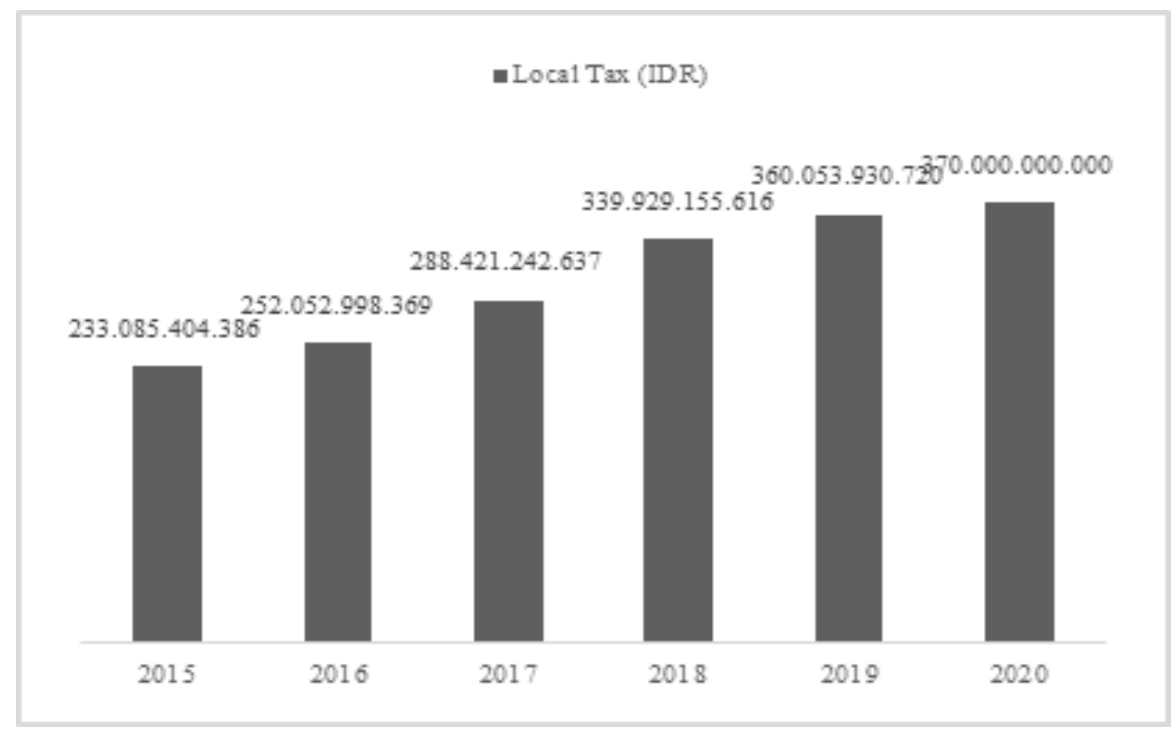

Figure 2

The Tax report before and after Online Tax Payment System

Source: Regional Financial Revenue and Asset Management Board, 2019

The implementation of Online Tax Payment System is based on Surakarta Mayor Regulation Number 21 of 2017 on Procedures for Implementing the Online System on Tax Business Transaction Data in Regional Tax Payments Supervision. Furthermore, since one of the goals of Online Tax Payment System is increasing local tax to enhance Local Government Revenue, the legislative body supports the idea of Online Tax Payment System. Innovations such as Online Tax Payment System that utilize the online tax system run smoothly and target certain potential taxpayer sources.

Surakarta City Government collaborates with some banks to provide the online tax payment service since 2016. Regional Financial Revenue and Asset Management Board not only cooperates with banks to develop Online Tax Payment System, but also with other stakeholders, including Communication, Information, Statistics, and Encoding Office as the network infrastructure coordinator that integrates Online Tax Payment System in Solo Destination application, and private sector as the network service provider.

Moreover, Regional Financial Revenue and Asset Management Board collaborates with the Audit Board of the Republic of Indonesia, and the Inspectorate of Surakarta City to supervise the financial system used in Online Tax Payment System. The Online Tax Payment System is being awarded at the Provincial level as a Top 10 Central Java Public Service Innovation in 2019 from Central Java Province (Priyanto, M.A. (October 23, 2019).

\section{3) Innovation in Public Work Integrated Information System} Public Works Integrated Information System is the third winner of 
Exhibition of Innovation Works in 2017. This innovation is arisen to be an integrated system to compile work reports from division in Public Works and Urban Planning Office due to lack of integrated data base in the field of this office that affects reporting performance and delay in report submission (E.N. Andraini, Public Works and Urban Planning Office. Moreover, there is a complaint function in this website to encourage people to apply their complaints related to Public Works and Urban Planning Office field such as infrastructure through website or mobile phone.

The Head of the Public Works and Urban Planning Office supported the emergence of Public Works Integrated Information System by encouraging staff to develop the Project of Change and allowed to use the inactive Urban Planning Office's website. As there is no innovation division in the Public Works and Urban Planning Office, most innovation ideas in this office come directly from the staff who attend the Leadership Education and Training. Maintenance of Public Works Integrated Information System is managed by the Head of Sub-Section of Planning, Evaluation and Reporting of the Public Works and Urban Planning Office.

Not only was the innovator of this innovation awarded third place and 7.5 million IDR to develop this innovative program in Exhibition of Innovation Works 2017, but she was also promoted. It proves that Project of Change created through the Leadership Education and Training can give benefit to the initiator.

However, there is similar function between Public Works Integrated Information System with Surakarta Complaints Service Unit that created in 2013, which is report complaints from all fields to Surakarta City Government. Thus, after one-year implementation, Public Works Integrated Information System has to be integrated with Surakarta Complaints Service Unit so that the complaints send by the people can be manage through that application. Now the function of Public Works Integrated Information System is still compiling work reports from division in Public Works and Urban Planning Office and giving information related Public Works to public in the website.

Public Works Integrated Information System is strengthened by the Head of the Public Works and Urban Planning Office Decree to implement this integrated system and also manage innovation in the office. On the other hand, there is no regulation in the city level for Public Works Integrated Information System that makes this innovation barely recognized by the people.

Just like other information systems in Surakarta City Government, Public Works Integrated Information System is managed by the Public Works and Urban Planning Office with the help of Communication, Information, Statistics, and Encoding Office as the leading sector in ICT and web-based innovation. This system is integrated with the Surakarta Complaint System Unit so that all complaints submitted in Public Works Integrated Information System will also appear in the Surakarta Complaint System Unit. Thus, the utilization of technology will make system integration easier among several division of the organization (Andhika, 2018).

The legislative body support the existing of Public Works Integrated Information System just like other innovations created by participants of The Leadership Education and Training. Moreover, the integrated system of infrastructure project is really needed by the City Government. On the other hand, as stated by a member of Indonesian Democratic Party of Struggle, who also a Member of Commission I of Regional 
House of Representatives: "since there is a similar function with Surakarta Complaints Service Unit, it is better to maximize Surakarta Complaints Service Unit function without making new application with the same function."

\section{4) Innovation in Complaint Service Unit}

Different from three previous innovation that became winners in Exhibition of Innovation Works 2017, the Surakarta Complaint Service Unit is developed in 2013. The initiation of Surakarta Complaint Service Unit even existed before the establishment of Online People's Aspirations and Complaints Services managed by the central government.

The Surakarta Complaint Service Unit is established due to the collaboration idea from Bandung Trust Advisory Group (B_Trust) and European Union and Inspectorate of Surakarta City Government. B_Trust is an NGO that concerned in increasing public trust in the government through the concept of Complaint Handling Management.

Surakarta City Government has received a Fair Opinion without Exception from the Audit Board of Indonesia so it can be seen as a benchmark for the success of the Surakarta City Government in carrying out the planned program. However, it is important for the local government to give space to the community to provide opinions (assessments, suggestions, and proposals) for the implementation of the program, as a reference for future evaluation and planning of the program. Hence, this reason encourages Surakarta City Government to initiate the collaborative innovation with B_Trust and the European Union who had a program to improve public services in the local government, namely NSA-LA II (NonState Actors-Local Authorities). This program targeted two major programs, namely Procurement Reform and Public Complaint Handling System.

Moreover, the idea of Surakarta Complaint Service Unit is relevance with the main task and function of Inspectorate, which is helping the mayor foster and supervise the implementation of government affairs that are the authority of the region and the assistance task by the regional apparatus. The Inspectorate was chosen as leading sector of Complaint Handling Management due to their function that could provide added value in encouraging the other offices to follow up on public complaints.

The mayor accepted the initiation of Surakarta Complaint Service Unit, a pilot project proposed by an NGO, in order to encourage community participation in monitoring and evaluating development programs in Surakarta City as well as building community trust and showing that complaints can lead to improvements if managed well. This argument from an auditor of Inspectorate is aligned with the statement of a former staff of B_Trust who involve in the making of Surakarta Complaint Service Unit, "the mayor's commitment started from the establishment of Surakarta Complaint Service Unit and positive mindset about complaints that considered as an opportunity to increase public service is said as the main factors that maintain the existence of Surakarta Complaint Service Unit."

In terms of budgeting, Surakarta Complaint Service Unit was fully funded by the European Union through the B_Trust from 2013 to 2015. After the commitment of the mayor to support Surakarta Complaint Service Unit, it became fully funded by the Surakarta City Budget in 2015. As this innovation accepts complaints from the community to enhance the local government performance, the legislative body supports this innovation by 
providing budget for Surakarta Complaint Service Unit development.

Surakarta Complaint Service Unit was initially established with Surakarta Mayor's Regulation Number 25 Year 2013, which then renew every year, and most recently renewed in 2019 with Surakarta Mayor's Regulation Number 29 of 2019 on Surakarta Complaint Service Unit. It is also strengthened with Mayor Decree Number 337.05/171 of 2019 on Managers of the Surakarta Complaints Service Unit.

At first, Surakarta Complaint Service Unit was a web-based complaint system, but it currently accepts complaints on the City Government's official social media sites, by telephone, email, and the websites/applications of a number of City Government Offices. Since Surakarta Complaint Service Unit is integrated with Solo Destination, all relevant usersapplication managers, Communication, Information, Statistics, and Encoding Office, related City Government Offices, and people making complaints-can access it via smartphone. Each complaint can be directly followed up within a period of three days.

Even though the leading sector of Surakarta Complaint Service Unit shifting from Inspectorate to the Statistical and Coding Informatics Communication Office since 2017, Surakarta Complaint Service Unit still running until now. Inspectorate role changes only as supervisor for the implementation of its innovation and the Communication, Information, Statistics, and Encoding Office as leading sector manage Surakarta Complaint Service Unit 24 hours. The complaints that are submitted by the community in Surakarta Complaint Service Unit have to be answered immediately within three days by the office that received complaints from the public. If there is complaint that have not been answered by the office, the admin from Communication, Information,
Statistics, and Encoding Office will remind the office. This collaboration cannot run smoothly without participation of all stakeholders in this complaint system. From 2017 to 2019, there are increasing complaints that issue by the community from 421 to 843 complaints.

For the community, Surakarta Complaint Service Unit is considered as a forum or mediation that can guarantee the arrival of complaints, proposals, and suggestions for the Government in carrying out programs in order welfare of the community. Surakarta Complaint Service Unit has a big role as a means of facilitation and transparency for the City Government of Surakarta in order to build trust from the community.

Moreover, the existence of Surakarta Complaint Service Unit has had a positive impact on the performance of the Surakarta City Government. Some government policies in the form of regulations emerged after there were complaints from the public. For example, Regional Regulation Number 9 of 2014 on Conducting a Boarding House Business that arises after there is a citizen complaint related to the boarding house which is used for improper activities.

\section{Discussion}

The in-depth interviews of four cases described on the previous section revealed some findings related to influencing factors of innovation in Surakarta City Government.

\section{1) Leadership}

The findings of this study indicate that leadership is the most important factor to foster and accommodate innovation. A leader who has a vision and mission to enhance the organization performance will support and welcome idea from the staff that will increase the performance of the organizations. It can be seen by the acceptance of the National Institute of 
Public Administration's assistance to develop the Innovation Lab by the Mayor. Moreover, Rudyatmo also accept innovative program proposed by an NGO to encourage community participation in monitoring and evaluating development programs in Surakarta City as well as building community trust and showing that complaints can lead to improvements if managed well. He has a positive mindset about complaints that considered as an opportunity to increase public service. These findings support previous research by Gabris et al. (2009) and Noor (2017) that acknowledged leadership credibility as factor that encourage the rise of innovation.

Furthermore, a change of leadership from the previous mayor to the recent mayor can bring new era for innovation. The new leadership of Joko Widodo from his predecessor bring a new style in the local government to produce solutions to solve their problems. His transformational leadership encourage the birth of innovative programs that later can be benchmark for other cities or region, even for the central government. It is in line with previous study by Borins (2001a) and Noor (2017) that stated about the new leadership can motivate the birth of innovation.

The head of local government still has a key role in innovation development, because if the regional head is active in the "public campaign" regarding the application of innovation, the innovation will develop. If not, it will fall into the trap of procedural/formal pathology. After the competition finish, no more development of the innovation. The mayor's commitment in supporting the development of innovation can be considered as the driver to maintain the innovation in the public sector, for instance in Surakarta Complaint Service Unit that was developed since 2013. As mentioned by Sorensen \& Torfing (2015), a combination of adaptive and pragmatic leadership is needed to foster public innovation. Adaptive leadership is aimed at deciding which public practices should be preserved and which should be adapted and transformed. Pragmatic leadership seeks to change the culture of public institutions by modifying established processes in ways that promote double loop learning and using current resources to solve problems.

However, different from Joko Widodo who gives innovation ideas based on a comparative study from other cities or developed countries that sometimes make the local government officials cannot follow Joko Widodo's idea, especially due to limitation of the regional budget, F.X. Hadi Rudyatmo tend to create policy based on basic needs of the community. This finding is in line with the It can be seen as his supportive acts in the birth of Death Certificate Administration Service that use proactive service in which the government officers give direct public service to the community. It is in line with the mission of the Mayor that is explained in the Surakarta Mayor Regulation Number 9 of 2016 on Regional Mid-Term Development Plan of Surakarta City Government 2016-2021. On the other hand, even though F.X. Hadi Rudyatmo supports the innovation idea from the local government officials, he has not issued innovations that appear directly from him yet. Most of his innovative ideas came from his subordinates.

Furthermore, in the era of F.X. Hadi Rudyatmo leadership, there is a greater number of innovations. However, it cannot be interpreted immediately because of the leadership of the mayor. A lecturer of Faculty of Social and Political Sciences of one university in Surakarta argues, "even though the characteristics of the application claimed as innovation, most of them arise because of the replication of something that is required by the central government, not purely from the regions." Thus, it takes a visionary leader who knows well all the 
potentials and problems in the city he leads to produce a sustainable innovative policy.

Moreover, the supportive head of office who encourage staffs to do innovation, will give a chance to the staffs to create innovations. Middle-to-lowerlevel employees are particularly critical to the successful implementation of new ideas. Aligned with this argument, a government officer stated that he proposed an innovation due to the staff own interest to improve the performance of their office that will make their routine works easier to be done. In this case, the emergence of Online Tax Payment System and Public Works Integrated Information System, arise from staff creative solution to solve the challengers they face in the office. It is also in line with Arundel et al. (2014) study in which stated that middle management and front-line workers might suggest creative ideas and promote their growth.

\section{2) Organizational climate}

The findings in this study show that the organizational climate is related with incentives/rewards, ICT facilities, clear goals, and organizational structure. It can be seen that the incentives/rewards for staff who initiate innovation and ICT facilities, have an impact to enhance innovation in the public sector.

In public service delivery, distance and time are indirect costs for the citizen. In the case of Surakarta City Government, ICT facilities are used to shorten the time to deliver public service to the community. The development of ICT facilities brings a significant impact to the birth of innovation produced in this city. It is aligned with study from De Vries et al. (2016) who stated that ICT is can be drivers or barriers in the public sector innovation. Moreover, for ICT-based innovation implementation, Surakarta City has the potential to strengthen infrastructure because the area is only $44 \mathrm{Km} 2$ so it will become more compact.

In order to make community access application easily through smart phone and website, it is important to connect all those application on a Solo Destination platform. It is aligned with the study from Bekkers et al. (2013) about ICT as an important source of innovation, which makes new services, new types of organization, new service processes, or new governance arrangements possible. In addition, ICT may provide a knowledge-sharing, information-sharing and communication infrastructure that helps to connect and develop ideas across all kinds of boundaries. However, when innovation is understood to be limited to the application of ICT, then the quantitative level will grow rapidly, but the probability of sustainability is likely to stagnate. It is in line with the opinion from a member of Indonesian Democratic Party of Struggle, also a Member of Commission I of Regional House of Representatives who said: "it is better to maximize existing innovation-based ICT's function without making new application with the same or similar function."

Among four cases being compared, only Death Certificate Administration Service that created through the innovation division of Population and Civil Registration Office. With good communication with all divisions in this office, the Innovation Division and discuss it in the routine meeting so that they find an innovative solution. Meanwhile, in other offices that do not have innovation division, the offices tend to create innovative programs due to the mandatory to create Project of Change for some staff members who become participants of the Leadership Training Program. So, it will be a little bit difficult for other offices to encourage innovation if there is no support from the head of the office. However, with 
a good positive encouragement of the head of the office, innovation can be created.

Local governments must develop a culture of learning among employees. The key to success in creating this condition is the commitment of leaders and regional heads so that a wave of changes in learning culture and work culture that will occur, receive full support from elements of leadership in the region. It is in line with the government officers' Law which has mandated local government agencies to draw up plans for developing government officers' competencies whose implementation rules have also been contained in Government Regulation Number 11 of 2017 on Management of Civil Servants. The government officials' competency development plan is prepared as a guideline in preparing work program planning and implementing the work program based on a merit system in the context of strengthening public sector accountability in the regions.

Empirical work suggests that frontline employees are important sources of innovation in public sector organizations. By reviewing awardwinning innovations in government, Borins (2001a) found that innovators were not usually senior managers but street-level bureaucrats. Middle-to-lower-level employees are particularly critical to the successful implementation of new ideas. However, Osborne \& Brown (2011) study stated that individual agency by itself is a necessary but not a sufficient condition for innovation in public service organization.

The existence of rewards for innovation initiators are in the form of incentives and also the promotion of positions. For instance, the winners of Innovation Lab competition are entitled to get money considered as extra coaching money to develop their innovation in the future. Some staffs who initiate innovation also can get promotions to a higher position. It is in line with Noor (2017) study about rewards as a supportive organizational climate.

On the other hand, there are some innovations that is developed in a short time, such as Public Works Integrated Information System. Even though some functions on Public Works Integrated Information System have to be integrated with previous innovations, such as Surakarta Complaints Service Unit, the birth of the Public Works Integrated Information System is still based on the real problem face by the staff in doing their daily work. The short time in developing innovation that is not based on real problem faced in the workplace will have high possibility to fail in the implementation.

\section{3) Enabling Environment}

The findings demonstrate that a positive political situation, regulatory aspects, good participation in the network, and inter-organizational relationship will support innovation in the public sector. It can be found that the regulatory aspect is the second important factor in the implementation of an innovative program and its sustainability.

In terms of regulatory aspects, there are several regulations from the Central Government that try to enhance innovation in local government. The role of the central government is considered dominant. It can be said that some of the regional innovation could be pseudo-innovation, which grew because of the supply-driven central government, not because of demand-driven from the community that responded by the city government. However, it is not that case in Surakarta City Government. From four cases being analyzed, three of them emerge due to problems in the real situation in their office, such as Death Certificate Administration Service, Online Tax Payment System, and Public Work 
Integrated Information system. While Surakarta Complain Service Unit born due to the needs of the local government to increase public trust in the government through evaluation from the community. It is aligned with Borins (2001a) study which argues that most of innovation is not crisisdriven, but instead a proactive reaction to internal challenges or opportunities.

Moreover, Surakarta City Government has supportive regulation to enhance innovation in the public sector. For instance, the Surakarta Mayor Regulation Number 9 of 2016 on Regional Mid-Term Development Plan of Surakarta City Government 2016-2021, innovation become one of the strategic issues in this mid-term development plan document. Furthermore, there is the Regional Action Plan of Regional Innovation System 20162020, ICT Master Plan 2016, as well as Smart City Master Plan 2018. These documents contain development programs that encourage regional innovation, one of which is the support of information and communication technology in its implementation.

In addition, there are some supporting regional regulations to maintain the existence and the sustainability of innovation, for instance Surakarta Complaints Service Unit, Death Certificate Administration Service, and Online Tax Payment System. However, the Public Works Integrated Information System only regulated with the Head of Public Works and Urban Planning Office Decree to implement this integrated system and also manage the innovation in the office. This condition makes this innovation barely recognized by the people. This finding aligned with an argument from a member from the Independent Panel Team as one of the assessors at the 2018 TOP 99 KIPP encourages all local governments to protect the innovations produced by Regional regulations, so that new regional heads will not simply eliminate existing innovations (Byu, 2018).

In terms of the political situation, both pro political party and opponent political party mostly support public sector innovation that has clear goals to solve the office problems and provide a good service to the public. As stated by one of government officer who involve in the Project of Change to create innovation: "besides providing the budget for the innovative program, the legislative member is also giving suggestions to the local government officers who in the process of developing the Project of Change."

Furthermore, some innovations in Surakarta City Government are created through collaboration with stakeholders, such as NGOs and private sectors. Surakarta Complaints Service Unit has emerged as a good collaboration between an NGO and Surakarta City Government. Moreover, the Online Tax Payment System innovation is now collaborating with five banks as partners in collecting Tax Revenue through a smartphone application. While the Population and Civil Registration Office also have a good collaboration with Public Health Service, urban village, Neighborhood Association, and Community Association, and the Ministry of Religion to implement their innovation, such as the Death Certificate Administration Service.

From the four cases above, it can be found that three factors are related and have a huge influence on the birth of innovation and its sustainability. In terms of leadership, the Mayor and head of office's role in supporting the emergence of innovation from staff members based on real problems in their office is crucial. It is followed by enabling factors such as regulatory aspects, as well as participation in network and inter-organizational relationship also play important role. 
Table 1

Influencing Factors of Innovation in the Public Sector

\begin{tabular}{|c|c|c|c|c|c|}
\hline No. & Factors & $\begin{array}{c}\text { Death Certificate } \\
\text { Administration } \\
\text { Service }\end{array}$ & $\begin{array}{c}\text { Online Tax } \\
\text { Payment System }\end{array}$ & $\begin{array}{c}\text { Public Works } \\
\text { Integrated } \\
\text { Information } \\
\text { System } \\
\end{array}$ & $\begin{array}{c}\text { Surakarta } \\
\text { Complaints } \\
\text { Service Unit }\end{array}$ \\
\hline 1. & $\begin{array}{l}\text { Visionary } \\
\text { leadership }\end{array}$ & $\begin{array}{l}\text { - The mayor } \\
\text { involves in the } \\
\text { innovation } \\
\text { development } \\
\text { The head of the } \\
\text { office encourages } \\
\text { his subordinate to } \\
\text { find innovative } \\
\text { problem solver }\end{array}$ & $\begin{array}{l}\text { - The head of the } \\
\text { office encourages } \\
\text { the use of ICT as } \\
\text { a problem solver } \\
\text { - The mayor } \\
\text { supports the } \\
\text { online tax } \\
\text { payment system } \\
\text { to increase Local } \\
\text { Government } \\
\text { Revenue. }\end{array}$ & $\begin{array}{l}\text { - The head of } \\
\text { office supports } \\
\text { her staff member } \\
\text { to develop this } \\
\text { innovation to } \\
\text { solve the } \\
\text { problems } \\
\text { - The mayor only } \\
\text { recognizes this } \\
\text { innovation after } \\
\text { the display stage }\end{array}$ & $\begin{array}{l}\text { The mayor } \\
\text { welcomes the } \\
\text { initiation of this } \\
\text { collaborative } \\
\text { innovation with } \\
\text { NGO }\end{array}$ \\
\hline 2. & $\begin{array}{l}\text { Regulatory } \\
\text { aspects }\end{array}$ & $\begin{array}{l}\text { A city-level } \\
\text { regulation }\end{array}$ & $\begin{array}{l}\text { A city-level } \\
\text { regulation }\end{array}$ & $\begin{array}{l}\text { Office-level } \\
\text { regulation }\end{array}$ & $\begin{array}{l}\text { A city-level } \\
\text { regulation }\end{array}$ \\
\hline 3. & $\begin{array}{l}\text { Participation in } \\
\text { network and } \\
\text { inter- } \\
\text { organizational } \\
\text { relationship }\end{array}$ & $\begin{array}{l}\text { A good } \\
\text { relationship } \\
\text { between } \\
\text { Population and } \\
\text { Civil Registration } \\
\text { Office, urban } \\
\text { village, and } \\
\text { Neighborhood } \\
\text { Association. }\end{array}$ & $\begin{array}{l}\text { A good } \\
\text { relationship } \\
\text { between Regional } \\
\text { Financial Revenue } \\
\text { and Asset } \\
\text { Management } \\
\text { Board with banks } \\
\text { and potential } \\
\text { taxpayers }\end{array}$ & $\begin{array}{l}\text { A close } \\
\text { relationship among } \\
\text { division in Public } \\
\text { Works Office and } \\
\text { integrated data } \\
\text { with other offices } \\
\text { related City } \\
\text { Planning data }\end{array}$ & $\begin{array}{l}\text { A good } \\
\text { relationship } \\
\text { between } \\
\text { Communication, } \\
\text { Information, } \\
\text { Statistics, and } \\
\text { Encoding Office, } \\
\text { other local } \\
\text { government } \\
\text { offices, and } \\
\text { community }\end{array}$ \\
\hline
\end{tabular}

Source: Author's identification, 2020

\section{CONCLUSIONS}

There are concluding points in this study regarding influencing factors of innovation in Surakarta City Government. Visionary leadership, organizational climate, and enabling environment has been proposed as the influential factors in the development of innovation in the public sectors. These influential factors can be either drivers or barriers that need to be addressed by the local government.

It can be found that the most influencing factor is leadership. Following the shifting of leadership in the local government, the innovation process in Surakarta City Government is continuing even though there are differences in the leadership style of both mayors. Such a mayor who has adaptive and pragmatic leadership style will encourage the foster of innovation in the public sector supported by the head of offices who give chances to their subordinates to create innovation as the problem solver to increase their performance.

The second influencing factor is regulatory aspect. Supportive regulation from central government combines with regional regulation related innovation and ICT drive the birth of public sector innovation in Surakarta City. The many ICT-based innovations are influenced by the appointment of Surakarta City as one of the Smart City pilot projects since Surakarta City Government has already had Regional Innovation System. However, the 
utilizing of ICT for public services is still depends on how the human resources who operate it since ICT is only an application installation. Some innovations that have a huge impact to the community usually supported with Mayor's regulation so that all of them can be disseminate to public.

Third, a good participation in network and inter-organizational relationship encourages innovation and its sustainability in the local government. Moreover, this study found that there is one innovation in the local government that is created through the collaboration between local government and NGOs. This collaborative innovation survives for almost a decade which also proves that NGOs idea combine with local government commitment can be a good collaboration.

Fourth, the central government still has a strong role in encouraging local government to do innovation in local government. This can be seen from the offering of innovation awards and providing supervision for local government to develop local government capacity through the Innovation Laboratory. However, some innovation awards are held by different ministries in the central government, and they created their own Information System to collect the innovation created in local government. This will lead to an unintegrated database and inefficient tasks for local government.

\section{RECOMMENDATIONS}

This study also proposes some policy recommendations. First, it is important to create local regulations to encourage the birth of innovation in the local government. Not only due to mandate from the central government, but also based on the real condition in the local government. Furthermore, an integrated policy regarding innovation is needed not only to create innovation through Leadership Education and Training and Innovation Laboratory, but also to evaluate and maintain the existing innovations to sustain local government programs. Second, it is also important for local government to provide opportunities in the form of local regulation that support collaboration with NGOs to foster innovation in the public sector as long as the vision and mission and ideas offered are innovative, useful, and in line with local government programs.

Based on the result of this study, the proposed theoretical framework can be used to analyzed innovation in the public sector in local government. It is strengthened some previous study about influencing factors of innovation in the local government. However, due to the limitation of data sources, resources, time, and methods of research, this study may be limited, this study is conducted only in one local government, Surakarta City Government, and focuses on ICT based innovations that emerged in the recent years following the development of ICT. Future studies could do cross-comparison between local governments in Indonesia that not only focus on ICT based innovation, but also non-ICT based innovation. Moreover, this study only focuses on the government side as the provider of innovation in the local government by using in-depth interviews with government officers, NGO, political party, and academician. So, it is recommended to conduct study more on public perception as the recipients of the public service innovation. 


\section{REFERENCE}

Andhika, L. 2018. Element and Factor Governance Innovation in Government Public Service. Inovasi Pembangunan: Jurnal Kelitbangan, 6(03), 207-222. https://doi.org/https://doi.org/10.35 450/jip.v6i03.112

Ariawan, A. 2020. Program Besuk Kiamat dan Sapu Kuwat Diharapkan Bisa Diduplikasi Daerah Lain, Retrieved from https://www.suaramerdeka.com/re gional/solo/221516-programbesuk-kiamat-dan-sapu-kuwatdiharapkan-bisa-diduplikasidaerah-lain. (March 13, 2020).

Arundel, A. Bloch, \& C., Ferguson, B. 2014. Measuring Innovation In The Public Sector in OECD Report. Retrieved from https://www.oecd.org/sti/087\%20\%20ARUNDEL\%20BLOCH\%20

Methodologies\%20for\%20measuri ng\%20innovation\%20in\%20the\%2 Opublic\%20sector.pdf

Bekkers, V.J.J.M., Tummers, L.G., Stuijfzand, B.G., Voorberg, W. 2013. Social Innovation in the Public Sector: An integrative framework. LIPSE Working papers (no. 1). Rotterdam: Erasmus University Rotterdam, Retrieved from

https://www.semanticscholar.org/p aper/SOCIAL-INNOVATION-INTHE-PUBLIC-SECTOR\%3A-ANBekkers-

Tummers/e94141a318649481d4f7 83aef5dc826f31aa7b9a

Borins, S. 2001a. Encouraging Innovation in the Public Sector. Journal of Intellectual Capital 2(3), 310-319.

Borins, S. 2001b. Innovation, success and failure in public management research: Some methodological reflections. Public Management
Review, 3 (1), 3-17. https://doi.org/10.1080/146166700 10009423

Byu. 2018. Bentengi Keberlanjutan Inovasi dengan Perda, Retrieved from https://www.menpan.go.id/site/beri ta-terkini/bentengi-keberlanjutaninovasi-dengan-perda. (July 19, 2018).

Cornell University, INSEAD, and WIPO. 2019. The Global Innovation Index 2019: Creating Healthy Lives-The Future of Medical Innovation. Retrieved from https://www.globalinnovationindex .org/about-gii\#currentreports

Cummings, C. 2015. Fostering innovation and Entrepreneurialism in Public Sector Reform. Public Administration and Development, 35(4), 315-328.

De Vries, H., Bekkers, V., \& Tummers, L. (2016). Innovation in the public sector: A systematic review and future research agenda. Public Administration, 94(1), 146-166. https://doi.org/10.1111/padm.1220 9

Gabris, G. T., Nelson, K., \& Wood, C. H. 2009. Managing for innovation in local government. Three core strategic factors. Governance Finance Review, 25(6), 22-28

Handini, R.S. 2016. Reformasi Berorientasi pada Dampak Kebijakan in Holidin, S., Haryati, D, \& Sunarti, E.S. Reformasi Birokrasi dalam Transisi. Jakarta: PT. Kharisma Putra Utama.

Hartley, J., Sorensen, J., \& Torfing, J. 2013. Collaborative innovation: A viable alternative to market competition and organizational entrepreneurship. Public Administration Review 73, 821830. 
Holidin, D., \& Handini, R. S. 2014. Sound Governance Analysis in the Innovation of Traditional Market Revitalization and Street Vendors Management. International Journal of Administrative Science and Organization, 21 (1), 17-26. https://doi.org/10.20476/jbb.v21i1. 4040

Koch, P., \& Hauknes, J. 2005. On innovation in the public sector today and beyond. PUBLIN Project on Innovation in the Public Sector, Report no. D20, Oslo: Nifu Step

Kusuma, H.B. 2017. Innovative Leadership for Innovation in Public Service. Jurnal Transformasi Administrasi, 07 (01), 1432-1443. Retrieved from http://jta.lan.go.id/index.php/jta/iss ue/view/32

Majeed, R. 2012. Defusing a Volatile City, Igniting Reforms: Joko Widodo and Surakarta, Indonesia, 20052011. Innovations for Successful Societies, Princeton University. Retrieved April 15, 2020 from http https://successfulsocieties.princeto n.edu/publications/defusingvolatile-city-igniting-reforms-jokowidodo-and-surakarta-indonesia2005-2011

Miles, M.B., Huberman, A.M., \& Saldana, J. 2014. Qualitative Data Analysis a Methods Sourcebook (3 ${ }^{\text {rd }}$ ed.). California: SAGE Publications.

Noor, I. 2017. Desain Inovasi Pemerintahan Daerah. Malang: UB Press.

OECD. 2016. Public-sector innovation in Indonesia, in Open Government in Indonesia. Paris: OECD Publishing, https://doi.org/10.1787/978926426 5905-10-en.

Osborne, S. P., \& Brown, L. (2011).
Innovation, public policy and public services delivery in the UK: The word that would be king? Public Administration, 89 (4), 1335-1350. https://doi.org/10.1111 /j.1467-9299.2011.01932.x

Prasetyo, A.P. 2017. Mengintegrasikan Reformasi Birokrasi dengan Inovasi Sektor Publik. Jurnal Analisis Kebijakan 1 (1), (49-62).

Priyanto, M.A. 2019. . Ini Daftar Top 10 Inovasi Pelayanan Publik Jawa Tengah, retrieved from https://jateng.tribunnews.com/2019 /10/23/ini-daftar-top-10-inovasipelayanan-publik-jawa-tengah. (October 23, 2019)

Rakhmatullah. 2016. Sejumlah Kepala Daerah dan Pemda Raih Government Award SINDO Weekly, retrieved from https://nasional.sindonews.com/ber ita/1100519/15/sejumlah-kepaladaerah-dan-pemda-raihgovernment-award-sindo-weekly. (April 12, 2016).

Rogers, E.M. (2003). Diffusion of Innovations. $5^{\text {th }}$ Edition. New York: The Free Press.

Sorensen, E., Torfing, J. 2015. Enhancing Public Innovation through Collaboration, Leadership and New Public Governance. In: Nicholls, A., Simon, J., Gabriel, M. (eds) New Frontiers in Social Innovation Research. London: Palgrave Macmillan. https://doi.org/10.1057/978113750 6801_8

Suripto, Prasetyo, A.P. 2014. Memahami Inovasi Administrasi Negara. In Dwiputrianti, S. et al. (2014:18), Handbook Inovasi Administrasi Negara [Handbook of State Administration Innovation]. Jakarta: Pusat Inovasi Tata Pemerintahan LAN. 
Sururi, A. 2017. Innovation of Policy in Public Administration Perspective toward the realization of Good Public Policy Governance. Spirit Publik, $12 \quad$ (2), 14-31. https://doi.org/10.2096/sp.v12i2.16 236

Wibowo, A.W. 2015. Pasangan RudyPurnomo Ditetapkan sebagai Pemenang Pilkada Solo. Retrieved from

https://daerah.sindonews.com/ berita/1070181/22/pasangan-rudypurnomo-ditetapkan-sebagaipemenang-pilkada-solo. Desember 2015

Wynen, Jan, Koen Verhoest, \& Bjorn Kleizen. 2017. More Reforms, Less Innovation? The Impact of Structural Reform Histories on Innovation Oriented Cultures in
Public Organizations. Public Management Review, 19 (8), 11421164.

Yin, R.K. 2014. Case Study Research: Design and Methods $5^{\text {th }}$ Edition. Thousand Oaks, California: Sage Publications.

Yunita, E. (2017). Innovation and Performance in Government. Jurnal Transformasi Administrasi, 07 (02), 1432-1443. Retrieved from https://jtajournal.com/index.php/jta/issue/vie $\mathrm{w} / 2$

Zulsyid. 2014. Prestasi Jokowi Semasa Jadi Wali Kota Solo, Retrieved from

https://www.bersosial.com/threads/ prestasi-jokowi-semasa-jadi-walikota-solo.13999/.Oct 17.2014. 